\title{
FREE SPEECH, FAIRNESS, AND FIDUCIARY DUTY IN BROADCASTING
}

\author{
LEe LOEVINGRR*
}

The first amendment of the Constitution, as everyone should know, guarantees free speech and a free press in the United States. By its literal terms the first amendment only prohibits Congress from making any law "abridging the freedom of speech, or of the press,"1 but the Supreme Court has expanded this to apply to action by any branch or agency of the federal government, ${ }^{2}$ as well as to the states, by incorporation through the fourteenth amendment. ${ }^{3}$ In effect the first amendment has operated principally as a limitation on state action, as relatively few federal laws have been attacked as infringing freedom of speech or the press. ${ }^{4}$ The precedents have been used on the basis of substantive similarity, without regard to whether the government action is congressional, state, municipal, or administrative. ${ }^{5}$

By its ringing rhetoric, as much as by its actual holdings, the Supreme Court has marked out a wide area within which expression is constitutionally protected against any government interference. Over the years the Court has declared:

Those who won our independence had confidence in the power of free and fearless reasoning and communication of ideas to discover and spread political and economic truth. Noxious doctrines in those fields may be refuted and their evil averted by the courageous exercise of the right of free discussion. ${ }^{6}$

For it is a prized American privilege to speak one's mind, although not always with perfect good taste on all public institutions.?

Freedom to distribute information to every citizen wherever he desires to receive it is so clearly vital to the preservation of a free society that, putting aside reasonable police and health regulations of time and manner of distribution, it must be fully preserved. 8

* Member, Hogan \& Hartson, Washington, D.C. Formerly Commissioner, Federal Communications Commission; Assistant Attorney General in charge of the Antitrust Division, U.S. Department of Justice; Associate Justice, Minnesota Supreme Court.

1 "Congress shall make no law respecting an establishment of religion, or prohibiting the free exercise thereof; or abridging the freedom of speech, or of the press; or the right of the people peaceably to assemble, and to petition the Government for a redress of grievances."

U.S. Const. amend. I, $\S$ I.

Tucker v. Texas, 326 U.S. $5 \times 7$ (1946); see also Hannegan v. Esquire, 327 U.S. 146, 155-56 (1946).

${ }^{3}$ Palko v. Connecticut, 302 U.S. 319 (I937); Cantwell v. Connecticut, 310 U.S. 296 (1937); Engel v. Vitale, 370 U.S. 421 ( 1962 ); Sherbert v. Verner, 374 U.S. 398 (1963); Edwards v. South Carolina, 372 U.S. 229 ( 1963 ).

"One of the few cases holding a federal law invalid under the first amendment is Lamont v. Postmaster General, $38 \mathrm{I}$ U.S. 301 ( 1965$)$. Most of the precedents cited in the opinions of this case involve state action.

${ }^{5}$ See note 4 supra.

'Thornhill v. Alabama, 3Io U.S. 88, 95 (I940).

${ }^{7}$ Bridges v. California, 3I4 U.S. 252, 270 (I94r).

${ }^{8}$ Martin v. Struthers, 3 I9 U.S. I4I, I46 (I943). 
[A] function of free speech under our system of government is to invite dispute. It may indeed best serve its high purpose when it induces a condition of unrest, creates dissatisfaction with conditions as they are, or even stirs people to anger. ${ }^{9}$

Men are entitled to speak as they please on matters vital to them; errors in judgment and unsubstantiated opinions may be exposed, of course, but not through punishment for contempt for the expression. ${ }^{10}$

Moreover, even where the utterance is false, the great principles of the Constitution which secure freedom of expression in this area preclude attaching adverse consequences to any except the knowing or reckless falsehood. ${ }^{11}$

For speech concerning public affairs is more than self-expression; it is the essence of self-government. ${ }^{12}$

It is firmly settled that under our Constitution the public expression of ideas may not be prohibited merely because the ideas are themselves offensive to some of their hearers. ${ }^{13}$

Although the area of constitutionally protected expression is wide, it is not unlimited. The Court has held that free speech is subject to exceptions "arising from the necessities of the case."14 In I897 the Court defined the exceptions by saying, "freedom of speech and of the press (Art. I) does not permit the publication of libels, blasphemous or indecent articles, or other publications injurious to public morals or private reputation." 15 In I942 the Court said:

There are certain well-defined and narrowly limited classes of speech, the prevention and punishment of which has never been thought to raise any Constitutional problem. These include the lewd and obscene, the profane, the libelous, and the insulting or "fighting" words-those which by their very utterance inflict injury or tend to incite an immediate breach of the peace. ${ }^{16}$

While the Court has characterized the exceptions to first amendment protection as "well recognized"17 and "well defined,"18 in fact they are neither. Obscenity is not within the area of constitutionally protected expression because it is "utterly without redeeming social importance."19 But this rationale gives little guidance in defining what comes within that category. ${ }^{20}$ It is highly doubtful that the "blas-

\footnotetext{
${ }^{0}$ Terminiello v. Chicago, 337 U.S. I, 4 (I949).

${ }^{10}$ Wood v. Georgia, 370 U.S. 375,389 (1962).

${ }^{11}$ Garrison v. Louisiana, 379 U.S. 64,73 (1964).

${ }^{12} \mathrm{Id}$. at 74 .

${ }^{13}$ Street v. New York, 394 U.S. 576, 592 (I969).

${ }^{14}$ Robertson v. Baldwin, 165 U.S. 275,281 (1897).

${ }^{10}$ Id. This dictum has been often repeated. Schenck v. United States, 249 U.S. 47 (I9I9); Frohwerk v. United States, 249 U.S. 204 (I9r9); Gitlow v. United States, 268 U.S. 652 (rg25); Terminiello v. Chicago, 337 U.S. I (I949); Beard v. City of Alexandria, 34 I U.S. 622, 642 (195I).

${ }^{10}$ Chaplinsky v. New Hampshire, 315 U.S. 568, $57 x$ (1942).

${ }^{17}$ Robertson v. Baldwin, I65 U.S. 275, 28I (I897).

${ }^{18}$ Chaplinsky v. New Hampshire, 315 U.S. 568, 57 I (I942).

${ }^{10}$ Roth v. United States, 354 U.S. $476,484-85$ (I957).

${ }^{20}$ See the variety of views expressed in Memoirs v. Attorney General, 383 U.S. 4 I3 (I966); Ginsberg v. New York, 390 U.S. 629 ( $x 968$ ); Interstate Circuit v. Dallas, 390 U.S. 676 (1968).
} 
phemous" or "profane" remain outside the scope of first amendment protection." Although a group libel statute has been sustained as valid, ${ }^{22}$ the libel exception to first amendment protection has been narrowed as the Court has held that even libelous statements about public officials are protected unless actual malice is proved.23 The government may constitutionally prohibit lotteries ${ }^{24}$ and speech presenting " $\mathrm{a}$ clear and present danger" of substantive evils that Congress has a right to prevent. ${ }^{25}$ Over-all, the general rule clearly is that all kinds of verbal expression, as distinguished from action or threat of action, are protected against government suppression with increasingly narrow exceptions in the fields of obscenity, libel, and incitement to breach of the peace.

\section{I}

\section{BRoadcasting and the First Amendment}

The application of these principles to broadcasting is more complex than first impressions suggest. There is no case squarely holding that broadcasting is within the scope of the first amendment. However, in dicta the Court has said that the principles of the first amendment apply to all media of expression, ${ }^{26}$ and that "we have no doubt that moving pictures, like newspapers and radio, are included in the press whose freedom is guaranteed by the First Amendment."27 The reasoning by which motion pictures are brought within the first amendment inescapably applies also to broadcasting. The Court reasons that motion pictures are "a significant medium for the communication of ideas" whose importance is not lessened by the fact they are designed to entertain, because their production and exhibition is a large-scale business conducted for private profit, or because they possess "greater capacity for evil," particularly among youth, than other modes of expression. ${ }^{28}$ However, the Court also says that the alleged capacity for evil "may be relevant in determining the permissible scope of community control."20

\section{A. FCC License Renewal Denial}

In any event, the Communications Act explicitly forbids the FCC to engage in

\footnotetext{
${ }^{21}$ Burstyn v. Wilson, 343 U.S. 495 (1952).

22 Beauharnais v. Illinois, 343 U.S. 250 (1952).

${ }^{23}$ N.Y. Times Co. v. Sullivan, 376 U.S. 254 ( 1964 ); Rosenblatt v. Baer, 383 U.S. 75 (I966); see also Pauling v. Globe-Democrat Pub. Co., 362 F.2d I88 (8th Cir. 1966); Ashton v. Kentucky, 384 U.S. I85 (I966).

24 In re Rapier, $x_{43}$ U.S. Ixo (1892); cf. FCC v. American Broadcasting Co., 347 U.S. 284 (1954).

${ }^{20}$ Schenck v. United States, 249 U.S. 47 (I9I9); cf. American Communication Ass'n v. Douds, 339 U.S. 382 (1950); Dennis v. United States, 34 I U.S. 494 (I95I); Watts v. United Statcs, 394 U.S. 705 (1969).

${ }^{26}$ Lovell v. City of Griffin, 303 U.S. 444,452 (1938).

${ }^{27}$ United States v. Paramount Pictures, Inc., 334 U.S. I3I, I66 (1948).

${ }^{28}$ Burstyn v. Wilson, 343 U.S. 495, 50r-02 (I952); see also Kingsley Int'l Pictures Corp. v. New York, 360 U.S. 684 (x959).

${ }^{29}$ Burstyn v. Wilson, 343 U.S. 495, 50I-02 (1952).
} 
censorship, ${ }^{30}$ and the Court has said that in this usage the term "connotes any examination of thought or expression in order to prevent publication of 'objectionable' material."31 This no-censorship provision has received surprisingly little discussion or attention in FCC decisions. In two early cases under the federal Radio Act (which contained a similar provision) ${ }^{32}$ the Commission denied the renewal of broadcast licenses mainly because of the broadcasting of objectionable programming. ${ }^{33}$ The first case involved an apparent medical charlatan who operated his station as an adjunct to the business of selling patent medicines to the public. ${ }^{34}$ The second case involved a minister who used the station licensed to a Trinity Methodist Church exclusively to broadcast his own brand of vilification and extremism. ${ }^{35}$ He had been convicted of contempt of court for defamation and used the broadcasting station as an instrument of blackmail. On appeal from the Commission decision, it was held that refusal to renew the license in these circumstances was not an interference with the right of free speech, "but merely the application of the regulatory powers of Congress in a field within the scope of its legislative authority." ${ }^{36}$ The court of appeals said the issue was simply whether there was "a reasonable exercise of governmental control for the public good." ${ }^{\prime 37}$ As the court stated the facts, it was obvious that the operation of the station did not serve the public good, so denial of its license renewal was held proper.

Although there has been no subsequent case under the Communications Act presenting precisely the same issues as the Trinity Methodist case, it seems likely that both the Commission and the courts would reach a similar result on similar facts today. However, there would probably be a somewhat more rigorous analysis of the first amendment issue and an effort to fit the facts within an exception to the first amendment or decide the case on other grounds. The distinction between the Trinity Methodist case and Near v. Minnesota ${ }^{38}$ was not explored in the opinion in the former, and has never been really analyzed by the courts.

In the Near case, state courts enjoined publication of a newspaper as a public nuisance under a state statute. Virtually the entire content of the newspaper consisted of malicious, scandalous, and defamatory articles, many obviously false. The injunction was issued after trial and was based on consideration of the newspaper's over-all record of publication. The Supreme Court held that despite a legislative

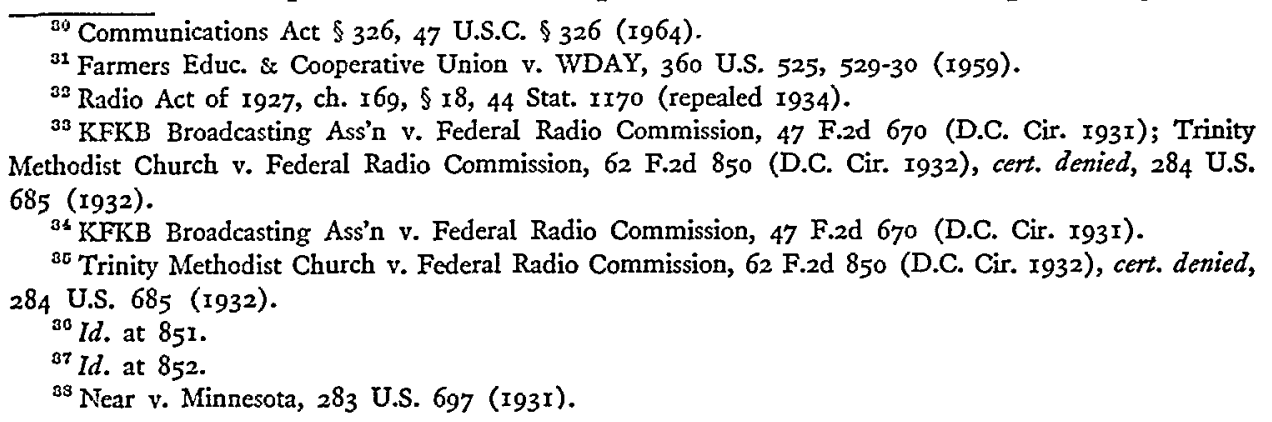


finding that a publication of this type was against the public interest, the statute authorizing its suppression was unconstitutional. The Court said,

If such a statute, authorizing suppression and injunction on such a basis, is constitutionally valid, it would be equally permissible for a legislature to provide that at any time the publisher of any newspaper could be brought before a court, or even an administrative officer (as the constitutional protection may not be regarded as resting on mere procedural details) and required to produce proof of the truth of his publication, ... . or stand enjoined. If this can be done, the legislature may provide machinery for determining in the complete exercise of its discretion what are justifiable ends and restrain publication accordingly. And it would be but a step to a complete system of censorship.

For these reasons we hold the statute, so far as it authorized the proceedings in this action ... to be an infringement of the liberty of the press guaranteed by the Fourteenth Amendment. We should add that this decision rests upon the operation and effect of the statute, without regard to the question of the truth of the charges contained in the particular periodical. ${ }^{39}$

\section{The Public Interest Argument}

The impact of the initial government action in both the Trinity Methodist case and the Near case was exactly the same-to prevent further public speech by the parties involved. In both cases the grounds for the action were the same-a finding after full hearing that the over-all record of past expression by the parties involved was scurrilous, defamatory, and contrary to the public interest. In neither case was the party involved restrained as to his private speech; only the public means of expression were involved-a radio station in one case, a newspaper in the other. Whatever the logical distinction between the cases may be, it is neither self-evident nor clearly stated in any opinion. ${ }^{40}$

The obvious difference between newspapers and broadcasting stations is that the latter require a license to operate because the nature of broadcasting is such that without some authoritative assignment of frequency, power, location, and other technical parameters, mutually destructive interference results. ${ }^{41}$ However, the necessity for control of the technical aspects of broadcasting does not logically imply either the necessity or propriety of control of the content of broadcasting, much less suggest the right to suppress particular types of expression which are within the

\footnotetext{
${ }^{80}$ Id. at 721, 722-23.

${ }^{10}$ The discussion of interstate commerce in the Trinity Methodist opinion is clearly irrelevant to the constitutional issue. In the Near case, the suppression was by state action so jurisdiction existed without interstate commerce. The interstate character of broadcasting transmissions is significant only as a basis for federal action. However, it does not abrogate the mandate of the first amendment, for if that werc the case Congress would be free to censor virtually every publication in the United States on the same grounds as it now legislates standards for their labor relations and wage policies. NLRB v. Joncs \& Laughlin Steel Corp., 30I U.S. I (I937); Associated Press v. NLRB, 301 U.S. 103 (1937); United States v. Darby, 3I2 U.S. I00 (I94I).

${ }^{41}$ National Broadcasting Co. v. United States, 319 U.S. rgo (1943).
} 
scope of first amendment protection when published in print. The common argument offered to bridge this logical gap is one attributed to the $N B C$ case: ${ }^{42}$ since the radio spectrum is so limited that only a few and not all who wish may broadcast, it is necessary for government to choose those who are to be so licensed; in making this choice the service offered, or to be offered, the public can and should be taken into account; program service is the essence of the service offered to the public; and therefore the government should grant or withhold licenses on the basis of a judgment of the programming. The difficulty with this argument is that the chilling effect of government suppression is precisely the same whether it is achieved by issuing a prohibitory injunction or by denying the renewal of a license and forbidding continued public expression without the license. It is precisely such suppression on the basis of judgment as to social value that is forbidden by the first amendment.

\section{The Scarcity Argument}

The scarcity argument with respect to broadcasting facilities logically militates as strongly against government suppression through the licensing power as in favor of it. The theory and spirit of the first amendment, as repeatedly stated by the Supreme Court, is that government action must not be exerted to suppress any expression, no matter how hateful or noxious in the view of officials, except within certain limited and defined categories. Where the opportunity for expression is unlimited, as in private speech or writing, government action to suppress some particularly objectionable expression may have a relatively limited effect on the general discourse. But where the opportunity for expression is limited and requires a government license, any action by government to suppress expression through the licensed facilities or to favor or disfavor particular kinds of expression will necessarily have greater influence and impact on all expression over similarly licensed facilities. Since the first amendment commands government neutrality with respect to the content of all types of expression, government action to control the content of expression on limited and licensed facilities is peculiarly inappropriate.

\footnotetext{
${ }^{40}$ National Broadcasting Co. v. United States, 3I9 U.S. I90 (I943), is usually cited for the proposition that the FCC has the right to control programming on the basis of a statement in the opinion of Justice Frankfurter that the FCC is not merely a traffic officer, policing electronic traffic, but has "the burden of determining the composition of that traffic." This view is apparently accepted by Justice White in the Red Lion case. However, in I946, Professor Chafee wrote:

"Did Justice Frankfurter mean to say that the FCC could control the contents of programs, contrary to what Justice Roberts had said a few years before [in F.C.C. v. Sanders Brothers, 309 U.S. 470, 474-75 (1940)]? Or did he merely have in mind the character of the persons participating in broadcasting and their methods of competition? The latter seems to me more probable and need cause no alarm."

Z. Chafee, Jr., Government and Mass Communications 58o (1947). My own investigation, including discussions with persons then associated with the Court, the FCC, and the National Association of Broadcasters, convinces me that the view taken by Chafee is the correct one and was generally accepted at the time of the decision.
} 
Unfortunately first amendment principles are usually tested in situations where the natural sympathies of normal, decent people tend to be engaged by the noble aims and decent purposes of the government officials seeking to exercise control and to be repelled by the ignoble goals and unworthy purposes of those whose freedom is at issue. There can be no reasonable contention that there is any real social value in speech of the kind involved in the Near case, the Trinity Methodist case, or the Terminiello case. But, as the Court has repeatedly pointed out, it is not the function of government to make such judgments of social value, and the first amendment commands legal toleration of ignoble as well as noble sentiments. It is difficult to escape the feeling that government should not permit, by license or otherwise, such public speech as was involved in the Trinity Methodist case. But it is even more difficult to find a wholly logical distinction between government suppression in the Trinity Methodist case and in the Near case.

\section{B. Licensee Editoralization}

In any event, under the Communications Act of 1934, government suppression of speech has generally remained at a relatively low level of informal administrative action with acquiescence by complaint licensees, and there has been no court decision similar to the Trinity Methodist case. ${ }^{43}$ However, in I94I in the Mayflotver case the Commission held that licensees could not express their own views in "editorials," but it reached this conclusion in the name of free speech. ${ }^{44}$ The Commission said,

Radio can serve as an instrument of democracy only when devoted to the communication of information and the exchange of ideas fairly and objectively presented. A truly free radio cannot be used to advocate the causes of the licensee. It cannot be used to support the candidacies of his friends. It cannot be devoted to the support of principles he happens to regard most favorably. In brief, the broadcaster cannot be an advocate. ${ }^{45}$

The issue, however, was not joined, since the applicant, to avoid hazard of its license, submitted an affidavit undertaking full compliance with the Commission's

\footnotetext{
${ }^{48}$ The denial of license renewals under the Communications Act of 1934 was sustained in Immaculate Conception Church v. FCC, 320 F.2d 795 (D.C. Cir. 1963), cert. denied, 375 U.S. 904 (1963), and in Independent Broadcasting Co. v. FCC, I93 F.2d 900 (D.C. Cir. I95I), cert. denied, 344 U.S. 837 (I952). Both cases involved denial of renewal applications after hearings in which it was proved that applicants had misrepresented to the FCC with intent to deceive and committed other fraudulent acts. In both cases applicants were disqualified for defect of character, and the action was sustained on appeal. Although programming is mentioned in passing, there is no discussion of a free speech issuc in either case, and no ruling on such an issue. In Palmetto Broadcasting Co., 33 F.C.C. 250 (1962), the Commission refused to renew a license because of misrepresentation to the Commission and obscene programming. The court of appeals affirmed on the basis of the misrepresentation, carefully avoiding consideration of the programming issue. Robinson v. FCC, 334 F.2d 534 (D.C. Cir. x964), cert. denied, 379 U.S. 843 ( 1964 ); $c f$. KWK Radio, Inc., 34 F.C.C. 1039 ( 1963 ), 35 F.C.C. 561 ( 1963 ), where a license was revoked because of the broadeasting of a fraudulent "treasure hunt."

"Mayflower Broadcasting Corp., 8 F.C.C. 333 (I94I).

${ }^{15} \mathrm{Id}$. at 340 .
} 
position, applicant's promises were accepted, and the license was renewed. This, unfortunately, is the common course in administrative proceedings although appellate courts often seem unaware of such reality.

In I947 the Commission, on its own motion, undertook to review the prohibition against broadcast editorializing, and after lengthy proceedings issued a report modifying, but not overruling, the Mayflower rule. ${ }^{46}$ The report cited the Mayflower case for the proposition that in the "presentation of news and comment the public interest requires that the licensee must operate on a basis of overall fairness, making his facilities available for the expression of the contrasting views of all responsible elements in the community on the various issues which arise." 47 Without expressly overruling the Mayflower case, the report concluded that "overt licensee editorialization, within reasonable limits and subject to the general requirements of fairness detailed above, is not contrary to the public interest." 48

\section{The Fairness Doctrine}

The "reasonable limits" of licensee editorialization have never been defined, imposed, or challenged, but the "Fairness Doctrine" that broadcast facilities must be made available for the expression of the contrasting views of all responsible elements in the community has remained effective. In I959 Congress amended the statutory requirement that equal time be afforded qualified candidates for any political office to create an exception for appearances on news programs, adding that this constituted no exception to the obligation of licensees "to afford reasonable opportunity for the discussion of conflicting views on issues of public importance."49 In June rg6g, the Supreme Court held the Fairness Doctrine valid and constitutional. ${ }^{50}$

While the Fairness Doctrine concerns program content, it does not involve any element of suppression, but rather requires the expression of all conflicting views on issues of public importance. This distinction between suppressing certain types of expression and requiring certain types of expression underlies two quite distinct lines of authority in FCC development, although it has not often been explicitly analyzed or considered..$^{51}$

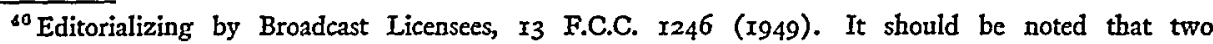
commissioners did not participate, one commissioner issued additional views, one commissioner issued a separate opinion, and one commissioner dissented, so the report represented the views of only two, or possibly three, of the seven commissioners. Nevertheless, the report has stood as the authoritative statement of Commission policy in this area up to the present time.

${ }^{8 T} I d$. at 1250 .

${ }^{48} \mathrm{Id}$. at I253.

${ }^{40}$ Act of Sept. 14, 1959, $\S \mathrm{x}, 73$ Stat. $55 \%$, amending 47 U.S.C. $\S 315$ (a).

${ }^{6}$ Red Lion Broadcasting Co. v. FCC, 395 U.S. 376 (1969).

51 The Supreme Court opinion in the Red Lion case glosses over this distinction and cites the Trinity Methodist Church case as merely another precedent in the early development of the Fairness Doctrine.
} 


\section{Control of Programming}

From its beginning the FCC has required licensees to keep logs showing the programs broadcast, classified by categories specified in FCC rules. It has generally been understood that the Commission expected, and required, that licensees have a minimum amount of programming in all categories. ${ }^{62}$ In I960 the Commission issued a detailed, prolix statement on the subject, stating that it was not authorized to "condition the grant, denial or revocation of a broadcast license upon its own subjective determination of what is or is not a good program." "53 However, the statement went on to say that since a broadcaster is required to program "in the public interest ...., it follows despite the limitations of the First Amendment and Section 326 of the Act, that his freedom to program is not absolute." The Commission said it was under a duty to review the programming of each licensee on a continuing basis, and then specified fourteen program categories which it considered "usually necessary to meet the public interest." The statement offers no explanation of the reasoning by which a statutory standard can imply a duty "despite" the constitutional standards of the first amendment. The statement also says that "the First Amendment forbids government interference asserted in aid of free speech, as well as governmental action repressive of it." This suggests a confusion between the prohibition against establishment of religion and abridgment of free speech. At best, the I960 statement on programming is so ambiguous and confused as to first amendment principles that it cannot be said to be clearly wrong. Nevertheless, it continues to be used and circulated by the Commission, constituting part of the application and renewal forms in current use..$^{54}$

Despite Commission inquiry regarding and consideration of program categories, the authority of the Commission to require specific categories of programming or minima within categories has not yet been squarely presented and decided, either by the Commission or the courts. There are three reasons for this. First, the Commission and its staff have avoided direct confrontation on the issue." Second, applicants and licensees have been unable or unwilling to force the issue. ${ }^{60}$ (In general, those who have been willing to force such an issue have lacked the resources, and those who have had the resources have been unwilling to hazard them for such

\footnotetext{
${ }^{52}$ See Loevinger, Religious Liberty and Broadcasting, 33 GEo. Wasr. L. REv. 631, 644 (1965).

${ }^{58}$ Report and Statement of Policy re Programming, 25 Fed. Reg. 729 I (r960).

* Amendment of Section IV (Statement of Program Service) of Broadcast Application Forms, I F.C.C.2d 439 ( 1965$)$, 5 F.C.C.2d 175 ( 1966 ). See especially concurring statements of Commissioner Loevinger, I F.C.C.2d 447 and 5 F.C.C.2d I 84 .

55 See Application of Lee Roy MCCourry, 2 P \& F Radio REg. 2d 895 (1964). The dissenting opinion of Commissioner Loevinger, concurred in by Commissioner Hyde, discusses the legal precedents and concludes that the Commission does not have authority to require specific categories of programs. $2 \mathrm{P} \& \mathrm{~F}$ RADio REg. 2d 898. As to the issues and difficulties in setting categorical standards for programming, see Loevinger, The Issues in Program Regulation, 20 FED. CoM. B.J. 3 (I966).

${ }^{50}$ In Application of Lee Roy MeCourry, stpra note 55, the applicant abandoned his application, as expected, following the Commission hearing order.
} 
a purpose.) Third, the majority of the Commission has become increasingly flexible in this matter, and, despite the strident demands of a minority, ${ }^{57}$ has increasingly relied upon a requirement that broadcasters survey the needs and desires of their communities, rather than seeking to impose an official standard as to the type of programming required. ${ }^{58}$

\section{Effects of Recent Social Turbulence}

The increasing political and social tensions and turbulence of recent years have inevitably been reflected in broadcasting. The range of public demands upon broadcasting has become greater, with part of the public demanding more permissiveness to accommodate unconventional and provocative programming, and another part of the public demanding stricter adherence to established standards of propriety and taste. Broadcasters have, uncertainly and somewhat hesitantly, broadened the range of programming to include more controversial and provocative material. The Commission has, somewhat timorously, moved toward the position that it cannot forbid or suppress any program material, other than that falling into a class excepted from first amendment protection, even by the usual indirection of refusing to renew a license. ${ }^{59}$ Concomitantly the Commission has become more insistent upon and expansive in applying the Fairness Doctrine. It has promulgated rules explicating and adding procedural requirements to the Fairness Doctrine in cases involving personal attacks and political editorials, ${ }^{60}$ and has applied the Fairness Doctrine to cigarette advertising. ${ }^{61}$ Both actions have now been upheld on judicial review. ${ }^{62}$

The most significant of these developments is the promulgation of the personal attack rules and the Supreme Court opinion sustaining their validity. The rules provide,

When, during the presentation of views on a controversial issue of public importance, an attack is made upon the honesty, character, integrity or like personal qualities of an identified person or group, the licensee shall, within a reasonable time and in no event later than I week after the attack, transmit to the person or group attacked (I) notification of the date, time and identification of the

\footnotetext{
${ }^{57}$ See statement by Commissioners Kenneth A. Cox and Nicholas Johnson, Broadcasting in America and the FCC's License Renewal Process: An Oklahoma Case Study, I4 F.C.C.2d I (1968).

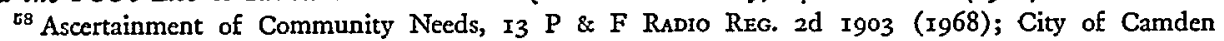
(WCAM), I8 F.C.C.2d 412 (I969).

${ }^{50}$ Pacifica Foundation, 36 F.C.C. I47 (I964); complaint of Anti-Defamation League, 6 F.C.C. 385 (1967), aff'd sub nom. Anti-Defamation League v. FCC, 403 F.2d I69 (D.C. Cir. x968), cert. denied, 393 U.S. 930 (1969).

${ }^{\circ 0}$ Amendment of Part 73 of the Rules relating to procedures in the event of a personal attack, 8 F.C.C.2d 721 ( 1967$)$, 9 F.C.C.2d 539 ( 1967 ), I2 F.C.C.2d 250 ( 1968 ), rev'd, 400 F.2d ro02 (7th Cir. 1968), rev'd sub nom. Red Lion Broadcasting Co. v. FCC, 395 U.S. 376 (1969). The rules appear at 47 C.F.R. $\$ \$ 73.123,73.300,73.598,73.679$ ( 1969 ), all of which sections are identical.

${ }^{01}$ WCBS-TV, Applicability of the Fairness Doctrine to Cigarette Advertising, 9 F.C.C.2d 921 (1967), ro F.C.C.2d I6 (I967), aff'd sub nom. Banzhaf v. FCC, 405 F.2d 1082 (D.C. Cir. I968), comments of Solicitor General requested, 395 U.S. 973 (I969).

${ }^{02}$ See notes 60 and $6 \mathrm{I}$ supra.
} 
broadcast; (2) a script or tape (or an accurate summary if a script or tape is not available) of the attack; and (3) an offer of a reasonable opportunity to respond over the licensee's facilities. ${ }^{63}$

These provisions do not apply to foreign groups or figures, to attacks made by political candidates or their spokesmen on other candidates, and to bona fide newscasts, news interviews, and on-the-spot coverage of news events, although the general Fairness Doctrine may be applicable to some of these exceptions. ${ }^{04}$

The editorializing provisions require a licensee who editorially endorses or opposes a political candidate within twenty-four hours thereafter to notify other candidates, or the candidate opposed, of the date and time of the editorial, provide a script or tape of the editorial, and offer a reasonable opportunity for response. Where editorials are broadcast within seventy-two hours of the election, compliance must be far enough in advance to enable those notified to prepare and present a timely response. ${ }^{65}$

The validity of these rules was attacked by an association of radio and television news directors, and the case was heard by the Supreme Court together with a case arising before the promulgation of the rules and involving a ruling by the FCC requiring a broadcasting station to provide free time for reply to a personal attack under the general provisions of the Fairness Doctrine. ${ }^{68}$ The Court held that the Fairness Doctrine as developed and stated in the opinions of the Commission and the personal attack and editorializing rules were within the statutory authority of the Commission and that they "enhance rather than abridge the freedoms of speech and press protected by the First Amendment."

The Court gave an expansive interpretation both to the power of the Commission and the Fairness Doctrine itself. The Court says that the duty imposed by the Fairness Doctrine is as follows:

The broadcaster must give adequate coverage to public issues, ... and coverage must be fair in that it accurately reflects the opposing views .... This must be done at the broadcaster's own expense if sponsorship is unavailable . . . . Moreover, the duty must be met by programming obtained at the licensee's own initiative if available from no other source. ${ }^{67}$

Under the rules, when a personal attack is involved, or a candidate is attacked or endorsed in a political editorial, the person attacked or the candidates entitled to reply must be offered reply time to use personally or through a spokesman. These obligations differ from the general fairness requirements in that the broadcaster has the option of choosing the method of presentation and spokesmen for expressing

\footnotetext{
${ }^{03} 47$ C.F.R. $\$ 73.123$ (a) (I969).

${ }^{\text {B4 }} 47$ C.F.R. $\$ 73.123$ (b) (I969).

${ }^{85} 47$ C.F.R. $\$ 73.123$ (c) (r969).

${ }^{60}$ Red Lion Broadcasting Co. v. FCC, 395 U.S. 367 (I969).

${ }^{67}$ Id. at 377 .
} 
positions that are not within the scope of the personal attack and political editorializing rules.

The Court reasons that these requirements are well within the mandate to protect the public interest, and that Congress has made it plain that the public interest requires broadcasters to discuss both sides of controversial public issues. The Court recognizes that "broadcasting is clearly a medium affected by a First Amendment interest, ... [but] differences in the characteristics of news media justify differences in the First Amendment standards applied to them." 68 Since only a tiny fraction of those who seek to communicate by radio can do so, "it is idle to posit an unabridgeable First Amendment right to broadcast comparable to the right of every individual to speak, write, or publish."69 The core of the Court's reasoning is in these passages: $:^{70}$

No one has a First Amendment right to a license .... As far as the First Amendment is concerned those who are licensed stand no better than those to whom licenses are refused. A license permits broadcasting, but the licensee has no constitutional right to be the one who holds the license or to monopolize a radio frequency to the exclusion of his fellow citizens. There is nothing in the First Amendment which prevents the Government from requiring a licensee to share his frequency with others and to conduct himself as a proxy or fiduciary with obligations to present those views and voices which are representative of his community and which would otherwise, by necessity, be barred from the airwaves.

... It is the right of the viewers and listeners, not the right of the broadcasters, which is paramount.

... It is the right of the public to receive suitable access to social, political, esthetic, moral, and other ideas and experiences which is crucial here. That right may not constitutionally be abridged either by Congress or by the FCC.

....

... It does not violate the First Amendment to treat licensees given the privilege of using scarce radio frequencies as proxies for the entire community, obligated to give suitable time and attention to matters of great public concern. To condition the granting or renewal of licenses on a willingness to present representative community views on controversial issues is consistent with the ends and purposes of those constitutional provisions forbidding the abridgement of freedom of speech and freedom of the press.

Whether by happenstance or intent, these views were echoed and emphasized within two weeks of their utterance in a decision by the Court of Appeals for the District of Columbia. Writing for the court was Judge Warren Burger, who has since become Chief Justice of the United States. In his last opinion as a circuit judge, Judge Burger said,

\footnotetext{
${ }^{88} 1 d$. at 386 .

${ }^{00}$ Id. at 388 .

${ }^{70} I d$. at $389-90,394$.
} 
The infinite potential of broadcasting to influence American life renders somewhat irrelevant the semantics of whether broadcasting is or is not to be described as a public utility. By whatever name or classification, broadcasters are temporary permittees-fiduciaries - of a great public resource and they must meet the highest standards which are embraced in the public interest concept. The Fairness Doctrine plays a very large role in assuring that the public resource granted to licensees at no cost will be used in the public interest. ${ }^{71}$

Thus it now seems clearly established that the first amendment prevents the Commission from suppressing the expression of any views that are not within one of the judicially established exceptions to first amendment protection, ${ }^{\mathbf{7 2}}$ and that it permits the Commission to require adequate coverage of public issues accurately reflecting opposing views.

\section{The Licensee as a Fiduciary}

But the reasoning of the cases goes beyond this. The Court now speaks of the broadcast licensee as a "fiduciary" with obligations to the community and its public. With respect to broadcasting, the rights under the first amendment are those of the public to see and hear ideas and experiences, and these may not constitutionally be abridged by either Congress or the Commission. Such reasoning raises an entirely new issue going far beyond any that has heretofore been considered. What is the mandate of the first amendment with respect to this constitutional right of the public? The first amendment prohibits government action that suppresses speech and permits government action to require speech representing opposing views, but what government action is constitutionally commanded (if any)?

There is no clear and certain answer to this question, and probably the Supreme Court itself has not yet considered it, although it seems to have elevated the Fairness Doctrine to the height of a constitutional principle. At the very least, the Court has read the Fairness Doctrine into the terms of the Communications Act, and, at the most, it has incorporated it into the first amendment. In either case, it has deprived the FCC of power either to repeal or basically amend the Fairness Doctrine. In applying the first amendment to broadcasting, the Court has done it through the Fairness Doctrine principle, which results in a fiduciary duty of broadcast licensees with a corollary right in the public. The fiduciary duty can be defined, at least

\footnotetext{
${ }^{71}$ Office of Communication of the United Church of Christ v. FCC, - F.2d -, I6 P \& F Raplo Rrg. 2d 2095 (D.C. Cir., June 20, x969). Regardless of subsequent proceedings or disposition of this casc, it may be assumed that the passage quoted fairly represents Chief Justice Burger's views of this general subject.

${ }^{72}$ United Federation of Teachers and WBAI-FM, I7 F.C.C.2d 204 (1969). It is noteworthy that Commissioners Cox and Johnson concurred in this decision although the former dissented and the latter abstained in Complaint of Anti-Defamation League of B'nai B'rith, 6 F.C.C.2d 385 (1967), which involved virtually the identical issue. It is also noteworthy that the latter case was affirmed by the court of appeals in an opinion written by Chief Justice (then Judge) Burger. Anti-Defamation League of B'nai B'rith v. FCC, 403 F.2d I69 (D.C. Cir. I968).
} 
in very general terms, as that of giving adequate coverage to public issues and accurately reflecting opposing views. The corollary right is harder to specify. The right of the public is to hear all views, not all individuals. Indeed, it is the very impossibility of giving all individuals access to broadcasting facilities that is said to give rise to the imposition of the fiduciary duty and its corollary right. Yet if there is a legal right there must be some mode of enforcement.

\section{How Would Fiduciary Duties be Enforced?}

The superficially obvious answer to this question is that the FCC enforces the fiduciary duty of broadcasters. But this proposition raises as many questions as it answers. Is the FCC to be an active investigator, prosecutor, and advocate, as well as adjudicator of broadcasting fairness? If so, we have probably established government censorship under the rubric of "fairness." Broadcasters are entirely dependent upon the FCC for their economic existence. The power of licensing, revocation, and renewal or denial of renewal is a discretionary power that is largely unreviewed and ultimately unreviewable. ${ }^{73}$ Every broadcasting operation is subject to a host of technical regulations and sooner or later is bound to violate some of them. There may be differences of opinion as to the seriousness and the sanctions of almost any violation, and the attitude of the Commissioners or their staff toward a broadcaster cannot be assumed to be wholly devoid of possible influence toward such issues. Consequently a prudent and responsible broadcaster is likely to be very responsive to the views of FCC commissioners and staff, regardless of his own judgment as to public needs or demands. Though not often articulated in this context, the fact has become a stereotype of FCC thinking which is reflected in the cliché of "regulation by the lifted eyebrow." This simply indicates recognition of the fact that occasional martyrs or heroes will assert their independence regardless of consequences to themselves; but, in general, people will bend to the will of those who wield power over them, and the independence of individuals and enterprises will be inversely proportional to the power government thus exerts.

Although these problems arise in a slightly different factual context with respect to broadcasting, they are by no means new problems. In the r 940 os the same problems were considered by the Commission on the Freedom of the Press established under the aegis of the University of Chicago. ${ }^{74}$ The Commission considered, and approved, the principle of the obligation of public service on the part of the press. Referring to this, Professor Chafee, the distinguished reporter for the Commission, first notes, "The ideal under consideration is for the press to give all sides of controversial public issues, or at least all sides which are supported by a substantial group

\footnotetext{
${ }^{73}$ For insight into some aspects of the problem, see Jaffe, WHDH: The FCC and Rroadcasting License Renervals, 82 Harv. L. REv. 1693 (r969).

7t See Z. Chafee, JR., Governinent and Mass Communications (1947).
} 
in the community with a modicum of reasonableness." ${ }^{35}$ Then, with respect to this ideal, he wrote as follows:

My conclusion about the public service theory is that for the most part it represents a moral and professional obligation of the press, not a legal obligation. ${ }^{70}$

The demand that every newspaper shall always live up to the moral obligation of complete fairness to both or all sides of controversial questions comes with ill grace from preachers, professors, and writers who have brains enough to know how hard it is to attain accuracy and impartiality in statements of fact-not to mention expressions of opinion. It is a mistake to insist on the aseptic ideal of a very, very perfect press. The most we can ask is that the men who operate the instrumentalities of communication shall feel strongly the need of the community for even-handed presentation of all the relevant facts and do a really good job in meeting that need-not a perfect job, for who of us can point to that in his own works. ${ }^{77}$

The press should not be responsible for its quality and points of view to the government any more than to the advertiser or to the friends of the owner. The true responsibility of the press is to the individuals who read and listen and inwardly digest. ${ }^{78}$

Although the legal basis for government control of broadcasting is different than for the printed press, the dangers of government influence and of enforced conformity to some official standards are no less, and probably greater. Even in tyrannical dictatorship there is the possibility of a clandestine and "underground" press. But with modern electronic instrumentation there is virtually no possibility of an "underground" broadcasting service. So, whatever the legal foundation for control may be, the dangers and evils of government censorship are no less in the field of broadcasting than in the area of the print media.

\section{Fiduciary Duty Circumscribes FCC Action}

Thus with the declaration by the Supreme Court that in the field of broadcasting the constitutional right of free speech belongs to the public and that this is matched by a fiduciary duty on the part of broadcasters to present opposing views, the mediating principle between the right and the duty becomes that of fairness, and a necessity arises for application of this principle in cases of conflict by a tribunal with judicial objectivity and neutrality. Whatever may be the case in other areas of administrative law and broadcasting, in the sensitive area of reporting news and

\footnotetext{
${ }^{75} I d$. at 628 .

${ }^{76} I d$. at 643 .

${ }^{77}$ Id. at $648-49$.

${ }^{78}$ Id. at 677 . Professor Chafee takes the position that broadcasting is in a different legal position than other mass media because of the necessity of government licensing. Id. at 634-43. However, it seems highly dubious that supervision of the accuracy or authenticity of the news is warranted by the authority to license, or permissible under the first amendment, even though it is undertaken with fervent avowals of noncensorship and strict adherence to first amendment principles, as in Democratic National Convention Television Coverage, I6 F.C.C.2d 650 (1969).
} 
presenting opposing views on public issues, neither the FCC nor any other agency can be complainant, prosecutor, and impartial adjudicator-or hope to be accepted in such different roles. Under the Fairness Doctrine as now construed by the Court, the rights are those of the public, so it is reasonable to infer that enforcement of those rights will be by community initiative and complaint under established principles of general applicability. Government initiative and complaint would necessarily result from and represent the views of government officials that the content of some speech or expression had not been fair. This is hardly compatible with neutrality and objectivity in such a sensitive area. Impartiality and detachment are much more easily maintained when passing on the complaints of others than when acting as an enforcement agent. The role of zealous critic and reformer of broadcasting, pursued in extra-official activities as author and lecturer, which seems so attractive to some commissioners, is incompatible with the duty of determining the balance of fairness and the bounds of fiduciary duty which has now been thrust upon the Commission by the Court. Thus a corollary to the first amendment rights of the public and fiduciary duty of the broadcaster is the impartiality of the Commission as a mediating adjudicator.

This has implications beyond the duty of personal restraint and a judicial attitude on the part of commissioners. It means also that the Commission, like the courts in first amendment cases, must be prepared to accept unpopular, and even hateful or despicable, expression as entitled to constitutional protection and the right to utterance. If the constitutional principles previously declared by the Supreme Court are to be maintained, the Commission cannot, as it has done in the past, declare that "atheists or persons with similar views" are not entitled to radio time, ${ }^{79}$ or write a long homily on the virtues of permitting all views regarding religious subjects which concludes by summarily denying the opportunity for atheists or freethinkers to present their views. ${ }^{80}$ The Commission has, at least in recent years, been reasonably tolerant in permitting unpopular, unfashionable, and uncongenial views to be expressed on broadcasting facilities. If the Supreme Court really means what it says in the Red Lion case, that first amendment rights to expression by broadcasting belong to the public, then the Commission has the onerous duty of requiring that even the most objectionable and unpopular views are given broadcast expression when the demand is made, provided only that they do not fall within one of the judicially recognized exceptions to the first amendment.

Another potential implication of the fiduciary duty of broadcasters to act as proxies for the public in presenting all views is that presentations pursuant to such

\footnotetext{
${ }^{70}$ Letter from Chairman Wayne Coy to Edward J. Heffron, President, Religious Radio Association, Aug. I8, I948, 3 P \& F Radio REg. 264 (I948).

${ }^{\text {so }}$ Robert H. Scott, 5 P \& F Radio Reg. 859 (1949), 25 P \& F Radio Reg. 349 (I963). See also Letter to Madalyn Murray, June $\mathrm{I} x$, I965, F.C.C. $65-476$ (not published); and Loevinger, Religious Liberty and Broadcasting, supra note 52.
} 
duty may be privileged against legal sanctions for libel. ${ }^{81}$ Certainly this is the logical implication of language in the opinions suggesting that the licensee has no more right of censorship than the FCC. By the same token, this approach involves revision of the traditional FCC concept of licensee responsibility. With respect to public issues, the primary responsibility of the licensee is not to approve or disapprove the content of material broadcast but to provide facilities for the broadcasting of views that are fairly representative of the range of opinion within the community. If this involves broadcasting views that are upsetting, and even shocking, to many, as it almost surely will in contemporary society, that consequence is the inescapable result of the first amendment mandate as construed by the Court and applied to the limited and licensed broadcasting facilities available in present technological and social circumstances.

\section{Scarcity Argument and the Fiduciary Theory}

As has been noted above, the scarcity argument, which is an important part of the Court's reasoning in the Red Lion case, is at best an equivocal support for the suppression of broadcast speech, and more logically argues against such an exertion of government power. On the other hand, the scarcity argument does rationally support an approach that undertakes to insure the opportunity for expression of all views, without the suppression or denial of any. Thus it is a logical underpinning for the fiduciary duty theory of broadcasting. If technology and the natural order limit the possibility of broadcasting facilities so that they are not available to all who seek them, it is neither unfair nor a limitation of any individual's right to free speech to require that the one chosen by government to receive the right to operate shall have a duty to provide opportunity for the expression of all views on such facilities. Of course, such a duty imposes some burden. But the burden is a relatively small one, and presumably is compensated by the privilege of operating on the assigned frequency for profit.

It does not follow that scarcity of broadcasting facilities justifies general government supervision of all broadcasting content or the establishment of programming standards. In fact, the assertion of general government control of programming, either through the imposition of pervasive standards or by means of over-all supervision, is substantially equivalent to suppression of disapproved program content, since, in effect, only officially approved program content is permitted and all other expression is suppressed. The imposition of a requirement for carrying certain limited categories of speech of social importance, under the Fairness Doctrine, does not have

\footnotetext{
${ }^{81}$ Such a result is supported, if not compelled, by Farmers Educ. \& Cooperative Union v. WDAY, 360 U.S. 525 (1959); and N.Y. Times Co. v. Sullivan, 376 U.S. 254 (1964); Garrison v. Louisiana, 379 U.S. 64 (1964); Linn v. United Plant Guard Workers, 383 U.S. 53 (1966); Rosenblatt v. Bacr, 383 U.S. 75 (1966); Pauling v. Globe-Democrat Pub. Co., 362 F.2d 188 (8th Cir. I966); Washington Post Co. v. Keogh, 365 F.2d 965 (D.C. Cir. I966), cert. denied, 385 U.S. ror I (1967).
} 
the same consequences, and so must be judged on a different basis. The Court has, at least by implication, recognized this distinction. In the Red Lion opinion it carefully notes that

When the Congress ratified the FCC's implication of a fairness doctrine in I959 it did not, of course, approve every past decision or pronouncement by the Commission on this subject, or give it a completely free hand for the future. ${ }^{82}$

We need not approve every aspect of the fairness doctrine to decide these cases. ... .

... We need not and do not now ratify every past and future decision by the FCC with regard to programming. ${ }^{83}$

An argument that the Red Lion decision has, by implication or otherwise, given the FCC general supervisory control of broadcast programming is not only unwarranted by the explicit language of the decision but is inconsistent with an analysis of the underlying rationale.

On the other hand, the scarcity argument does have implications beyond the scope of the decided cases. If the scarcity of broadcasting facilities warrants the imposition of a fiduciary duty under the first amendment on those privileged to operate such facilities, does the same reasoning require the same result in similar circumstances involving other media? Logically, the answer has to be that in similar circumstances the same legal consequences will follow. This raises the question whether newspaper facilities are not even more limited than broadcasting facilities. It is easily demonstrated that newspaper facilities are numerically more limited than broadcasting facilities. There are more than 6,500 radio stations (AM and FM) and over $x, 000$ television stations and the number is constantly increasing. ${ }^{84}$ In contrast, there are only about $I, 750$ daily newspapers published in the United States. ${ }^{85}$ Broadcasting stations are located in hundreds more cities than have daily newsapers, and all large cities have competitive broadcasting stations, although less than fifty cities have competitive daily newspapers. ${ }^{86}$

The arguments usually made to distinguish broadcasting scarcity from newspaper scarcity are that broadcasting is limited by the electromagnetic spectrum, whereas the number of newspapers is not limited by any natural phenomenon, and that broadcasting facilities are licensed by the government while newspapers are not. These arguments are based on differences between the media but not on differences that are necessarily significant with respect to the first amendment and the right of the public to free expression. So far as the opportunity for the utterance of all views is

\footnotetext{
${ }^{82}$ Red Lion Broadcasting Co. v. FCC, 395 U.S. 376,385 (I969).

${ }^{83} \mathrm{Id}$. at 396.

${ }^{84}$ See 34 FCC ANN. REP. II3 (r968). Current statistics on licensed broadcasting stations are published weekly in the periodical Broadcasting.

85 See Raymond Nixon, Trends in Newspaper Ownership (i968). See also Brief for the American Newspaper Publishers Ass'n as amicus curiae, Citizens Pub. Co. v. United States, 394 U.S. I3I (I969).

${ }^{80}$ Id.
} 
concerned, it does not make any difference whether facilities are limited by natural forces or economic forces. ${ }^{87}$ In either case they are quite beyond the control of the ordinary citizen; and in either case the limitation on the expression of views is the same. Indeed, the effectiveness of economic limitations is the whole foundation of our antitrust policy, which makes no sense otherwise. In antitrust cases in the newspaper field, the Court has clearly recognized these assumptions. ${ }^{88}$ Furthermore, at the present time the limitation of electronic communication facilities is in part the result of a deliberate choice by government agencies, including the FCC, which have chosen to permit fewer facilities than technology would allow for various economic and social reasons.

The fact that broadcasting facilities are licensed is simply a lawyer's jurisdictional argument, which logically has little to do with control of broadcast speech. The assignment of frequency, power, and other technical broadcasting specifications has no more to do with the content of what is uttered over broadcasting facilities than the government power to prohibit very loud noises has to do with the right to utter any views or sentiments quietly. Most newspapers move in interstate commerce, enjoy second-class mailing privileges, and hold various other governmentgranted rights which might serve as a jurisdictional basis for asserting control if the legislative and judicial branches should ever concur in seeking to do so.

It is not asserted here that newspapers should be subject to government control or to an officially imposed Fairness Doctrine. However, it is asserted that broadcasting and publishing have much in common, are more similar than dissimilar, and are likely to be treated similarly by government with respect to rights and duties. It is not a remote possibility that newspapers may be distributed electronically, either by the same means now employed in broadcasting, or by transmission techniques employed by broadcasting in the future. Technological developments are certain to make the distinction between electronic and print journalism less and less important. The legal status of broadcasting today is likely to be that of publishing tomorrow.

These suggestions are neither new nor without respectable advocacy. In 1946 the Commission on Freedom of the Press, with eminent membership and sponsorship, concluded, among other things,

We recommend that the constitutional guarantees of the freedom of the press be recognized as including the radio and motion pictures.

\footnotetext{
${ }^{87}$ Amicus curiae in the Citizens $P u b$. Co. case made a powerful showing that the number of newspapers that could be published was subject to inescapable economic limitations manifested in a secular trend throughout the United States. In deciding the case the Supreme Court did not even deign to notice the argument. Brief for the American Newspaper Publishers Ass'n as amicus curiae, Citizens Pub. Co. v. United States, 394 U.S. I3I (I969).

${ }^{88}$ Associated Press v. United States, 326 U.S. I (1945); Citizens Pub. Co. v. United States, 394 U.S. I3I (I969).
} 
We recommend that the agencies of mass communication accept the responsibilities of common carriers of information and discussion. ${ }^{89}$

In essence both of these recommendations have been adopted by the Supreme Court for broadcasting. But the Court has gone further. It has converted the responsibilities of broadcasting, with respect to information, into legal duties, and it has elevated these duties to constitutional status. There can be little doubt that these principles will be the law for a long time to come. ${ }^{90}$ The chances are great that the technology of broadcasting will change before these governing legal principles change.

\section{CONCLUSION}

Law, as Justice Holmes pointed out long ago, is more the result of felt social needs than of abstract logic. The Supreme Court sits as a kind of continuing constitutional convention, adapting the broad general provisions of the Constitution to the changing needs of contemporary society. On occasion, the Court, by way of implication or construction, writes a few additional provisions into the Constitution. There may be differing views as to the process or the reasoning by which the result was achieved, but the legal status of broadcasting with respect to the first amendment seems to be clearly established now.

A broadcast licensee has the same, but no greater, right to express his views over the licensed broadcast facilities as any other member of the public. The duty of the licensee is to give adequate coverage to public issues that is fair in that it accurately reflects opposing viewpoints. The right of free speech by broadcasting belongs to the public, not to the licensee, and the licensee is a proxy for the public with a fiduciary duty to insure the fair presentation of all viewpoints. It is all viewpoints that are entitled to be heard, not all individuals or all spokesmen, except in the cases, specified by statute or rule, involving political candidates or personal attacks. The FCC may specify procedures and applications of this fiduciary duty, but it may not constitutionally abridge the right of the public to receive the fulf range of views and information which the licensee's initiative discovers or responsible elements of the community demand or offer. These principles leave many questions unanswered and will no doubt create many practical problems in operation. That is usually the case with constitutional principles. These represent the Supreme Court's articulation of the needs of contemporary society and its construction of the first amendment in application to a technology of communication that could not have been dreamed of by those who first wrote the great principle of free speech into the Constitution. The first amendment has been rewritten for

\footnotetext{
${ }^{80}$ Z. Chafee, Jr., Government and Mass Communication 801-02 (I947).

${ }^{\text {oO It }}$ should be noted that seven justices concurred in the Red Lion decision, one did not participate because he had not heard the oral argument, and there was one vacancy. The opinion was written by Justice White, who is one of the younger members of the Court. Chief Justice Burger, who has taken office since the decision was rendered, has clearly stated similar views.
} 
298

Law and Contemporary Problems

the twentieth century. It is not certain that this latest revision will insure a free marketplace of ideas, prevent government censorship, and help maintain a democratic social and economic order. It never was certain that the principles of the first amendment would be successful. The ideal remains the same. The challenge now is to say what the ideal of free speech means and how it may be achieved in the confused, groping society of today's turbulent technological world. 